\title{
Building Social Europe Requires Challenging the Judicialisation of Citizenship
}

\author{
Susanne K. Schmidt
}

Which rights should European citizenship entail to protect the achievements of European integration, while overcoming its pitfalls? Should we aim to 'add stuff', as Ferrera suggests, or rather follow Joppke's plea for nonexclusive citizenship rights? I agree with Ferrera's diagnosis that EU citizenship has an isopolitical bias, it horizontally opens nationally shaped (and financed) welfare systems to citizens from other member states. However, in his 'detecting of the flaws' he overlooks the largely judicial genesis of citizenship rights, which are crucial for understanding the shortcomings of EU citizenship. In the following, I start by filling this gap. Because Ferrera's suggestions require political decisions, they are much welcome on this basis.

Since Maastricht, EU citizenship saw an impressive advancement from a rather symbolic Treaty addition to being the 'most fundamental status' (C-184/99 Grzelczyk). In the light of van Gend (26/62), Costa (6/64), Cassis de Dijon (120/78), and multiple other rulings, scholars of European integration have taken for granted how much the Court of Justice of the European Court (CJEU) shapes policy in the EU by interpreting the many policy objectives the Treaty contains (four freedoms, competition law, and then citizenship). For citizenship, the judicial development implied an increasing pressure on nationally financed welfare states to open up non-discriminately to EU citizens, even if economically inactive, and with few and recent ties. But in late 2014 the CJEU made clear that those entering a state but never intending to work and contribute (C-333/13 Dano) have no European right to claim equal access to funds.

Behind the extraordinary policymaking power of the CJEU is what Dieter Grimm calls over-constitutionalisation. ${ }^{1}$ An intergovernmental Treaty describing cooperation aims is policy-rich. If this Treaty is transformed into a constitution by declaring it directly effective and supreme, the Court's

Funding of Norface is gratefully acknowledged (www.transjudfare.eu).

1 Grimm, D. (2015), 'The democratic costs of constitutionalisation: the European case', European Law Journal 21: 460-473. 
interpretations of the Treaty acquire constitutional status themselves. For citizenship rights, this means that the rights enshrined in the Citizenship Directive or in the regulations on the coordination of national social security systems, have been shaped back and forth between the EU's judiciary and its legislature, with the latter not being able to overrule the former's constitutionalised rulings. ${ }^{2}$ Next to EU secondary law, CJEU case law directly shapes the social policy of member states.

This peculiar way of policymaking has repercussions. As rulings on single cases take generalised effect, the resulting policy is unable to cater equally well for the differences of national welfare systems. Its character of 'one size fits none' is more pronounced than a negotiated policy would be, where all member states could make their preferences known regarding national conditions and singularities. And, more seriously in our context, the CJEU is hardly legitimised for opening up national welfare systems to EU citizens. This is not to say that those advocating for welfare chauvinism know about the judicial background of the rules, but rather that memberstate governments would not have legitimated, absent judicial pressure, the partly far-reaching opening of national welfare systems even to those that have hardly contributed so far. For instance, following Styrelsen (C-46/12, 2013), EU students working 10-12 hours per week have gained access to Denmark's generous non-repayable student support. Labour-activating welfare states subsidise poorly paid EU citizens, implying that tax-financed inwork benefits may be higher than actual pay, resulting also in incentives for workers' exploitation. ${ }^{3}$

Nationally financed welfare state systems that are only coordinated at the EU level may need to balance openness and closure in the way of an 'earned' social citizenship excluding those that recently joined the national community for a transition period. ${ }^{4}$ This is not to say that internal EU migration currently takes a toll on the old member states. Overall contributions appear positive, and it is rather of grave concern that the poorer EU countries seem to lose out from the free movement rights of their citizens. ${ }^{5}$ But within the

2 Schmidt, S.K. (2018), The European Court of Justice and the Policy Process: The Shadow of Case Law. Oxford: Oxford University Press.

3 Ruhs, M. (2015), 'Is Unrestricted Immigration Compatible with Inclusive Welfare States? The (Un)Sustainability of EU Exceptionalism', Oxford: Compas, Centre on Migration, Policy and Society, Working Paper No. 125.

4 Kramer, D. (2016), 'Earning social citizenship in the European Union: free movement and access to social assistance benefits reconstructed', Cambridge Yearbook of European Legal Studies 18: 270-301.

5 Atoyan, R. et al. (2016), 'Emigration and Its Economic Impact on Eastern Europe'. IMF Staff Discussion Note; Sindbjerg Martinsen, D. \& G. Pons 
rich states the benefits of European integration, as of globalisation, do not appear to be distributed equally. The working class feels left out from the liberal consensus. This needs to, and could be handled better within the member states. But inevitably, like the free movement of capital, individual free movement rights can be used to free-ride on different member states' provisions or to engage in regulatory arbitrage. Empirically, this may be of much less relevance than tax evasion. But to those contributing to national welfare systems, to those having themselves difficulties making ends meet, arbitrage and lack of reciprocity undermines the legitimacy of national welfare alongside that of the EU. ${ }^{6}$

Are Ferrera's suggestions likely to remedy the situation? They strengthen the necessary political debate. If the opening of national protection systems to those with recent links and few financial contributions to the memberstate community lacks legitimacy, because solidarity is claimed with no reciprocity, his suggestion of an EU social scheme for those on the move appears the most promising. Those using their free movement rights, requiring support in the transition, should be compensated directly from the EU level to top up, for instance, their Bulgarian unemployment payments that do not allow them to look for a job in Denmark. ${ }^{7}$ In addition to Ferrera's argument, this would lessen the normative drawback of the immediate opening of national welfare. To me, it therefore appears better suited than his other suggestions of compensating for possible costs of 'hospitality'. The array of national welfare schemes and European funds already appears sufficiently confusing to the non-expert, so that more may be gained from greater transparency than from further additions. A division of competences, where the level of government granting rights also has to cover their costs would allow social Europe to progress from 'regulation' to 'allocation'. And it would bolster the EU's legitimacy if it could give added value to EU citizens moving to other member states.

Rotger (2017), 'The fiscal impact of EU immigration on the tax-financed welfare state: Testing the "welfare burden" thesis', European Union Politics 18 (4): 620-639, doi:https://doi.org/10.1177/1465116517717340.

Dustmann, C. \& T. Frattini (2014), 'The Fiscal Effects of Immigration to the UK', The Economic Journal 124 (580): F593-F643, doi:10.1111/ecoj.12181.

6 Beaudonnet, L. (2016) 'A threatening horizon: the impact of the welfare state on support for Europe', Journal of Common Market Studies 53 (3): 457-475.

7 Bruzelius, C., C. Reinprecht \& M. Seeleib-Kaiser (2017), 'Stratified Social Rights Limiting EU Citizenship', Journal of Common Market Studies 55 (6): 1239-1253, doi: https://doi.org/10.1111/jcms.12555. 
Such an EU citizenship could not treat newly settled third-country nationals on a par, in the same way as mobile EU citizens would have to 'earn' their equal rights in host member states. If I understand Joppke well, he argues against such exclusion and for a thin, liberal citizenship, reminding us of the dangers of national privilege and allegiance.

Intuitively, inclusion has greater appeal than exclusion, but possible costs to the achievements of advanced welfare states need empirical analysis. Highly differentiated societies rely on redistribution, social services, public education, and infrastructure. Solidarity and reciprocity are closely related, as Ferrera reminds us. A currently positive fiscal balance under conditions of EU free movement is insufficient proof, as there is no full opening and member states tread carefully to maintain their welfare schemes under the relative openness forced by the CJEU. If we fail to consider how redistribution could work in a context of encompassing non-discrimination without resulting in a race to the bottom of welfare services, we may strengthen rather than beat right-wing populism.

Freedom of movement and EU citizenship have liberating force for the individual. But they have to be embedded so that they do not undermine the republican basis on which they ultimately rest. ${ }^{8} \mathrm{~A}$ solely liberal notion of citizenship that does not exclude anyone, extending to third-country nationals, may be a citizenship for those whose fortunes do not seem to depend on collective action as they are individually imbued with sufficient resources. Is the inclusive, liberal citizenship vision possible without transforming it into a neoliberal nightmare of the fully liberated market-citizen? And is it really politically more attractive than a temporary exclusion from full equal treatment for those moving into other communities? An all-inclusive, truly cosmopolitan citizenship conception can hardly assure those fellow citizens that are losers of globalisation of our solidarity if they feel pitted against all humankind in need. It has been asked why the working class abandoned the Left. ${ }^{9}$ But the converse question similarly merits debate.

We all depend on the surplus of functioning, highly differentiated societies. The rising number of failed states, and increasing problems with rule of law even in EU member states show how much ridden with prerequisites the Western highly developed (welfare) state is. Joppke sees 'incompatible

\footnotetext{
Scharpf, F.W. (2009), 'Legitimacy in the multilevel European polity', European Political Science Review 1 (2): 173-204.

9 Rothstein, B. (2017), 'Why Has The White Working Class Abandoned The Left?', Social Europe, available at https:/www.socialeurope.eu/ white-working-class-abandoned-left.
} 
loyalty structures' on both sides of the openness v. closure cleavage that cannot be tied together by citizenship anymore. That does not bode well for the necessary political discussion of how open national welfare states should be and under which conditions they integrate newcomers. The decision cannot be left to courts that deal with it under the principle of non-discrimination. Different from democratic majorities, the judiciary is ill-equipped to take decisions on allocating resources. Non-discrimination as a principle neither gives clear guidelines, as it requires treating like cases alike, and unlike cases differently. For welfare states depending on redistribution, which are legitimate criteria for distinction?

Traditionally European integration has been market integration and as such it is not sustainable. But the building of communities sharing values and solidarity takes time. It cannot be surprising that the increasing economic and social heterogeneity through simultaneous deepening and widening of the EU resulted in challenges. To strengthen the sense of belonging, EU citizenship rights are important, but in order to have societal backing they need to be politically shaped and granted, not judicially. Has this not been amply demonstrated by the Brexit vote? Without entering this debate, which Ferrera opens, sustainable progress towards a real European Community is unlikely. Relying on courts is insufficient.

Open Access This chapter is licensed under the terms of the Creative Commons Attribution 4.0 International License (http://creativecommons.org/licenses/by/4.0/), which permits use, sharing, adaptation, distribution and reproduction in any medium or format, as long as you give appropriate credit to the original author(s) and the source, provide a link to the Creative Commons license and indicate if changes were made.

The images or other third party material in this chapter are included in the chapter's Creative Commons license, unless indicated otherwise in a credit line to the material. If material is not included in the chapter's Creative Commons license and your intended use is not permitted by statutory regulation or exceeds the permitted use, you will need to obtain permission directly from the copyright holder. 